\title{
AGRICULTURAL INVESTMENTS AS THE MAIN FACTOR INCREASING THE AGRICULTURAL SECTOR'S COMPETITIVENESS
} Raimjanova Madina Asrarovna, Dr. assoc.prof.
Tashkent Institute of Finance

\begin{abstract}
Investments in the agricultural sector of Uzbekistan are one of the most important factors of its development. The subject of the research is relations between volume of investments directed into Agricultural sector of the Uzbekistan's economy, its impact to agricultural output in terms of volume of production, food production index and value added indexes. To identify quantitatively above mentioned relations, methods of economic - mathematical modelling are employed in this research
\end{abstract}

Key words: investments, agricultural sector, agricultural output, food production index, value added JEL code: N55, O13

\section{Introduction}

Investments play a special role in the development of any sector of the national economy, including the restoration and development of the agricultural sector.

Investments in the agricultural sector are considered to be a valuable tool that contributes to a constant long-term income, since agricultural products have value. This means that investments in the agricultural sector are the most efficient and the most important instrument in the development of the current economy. The Government of Uzbekistan is developing a number of programs to attract investors both local and international to this crucial sector of the national economy. Though there are many declarations that investments are important to increase agricultural production, there is not yet quantitatively based research to demonstrate functional relation between volume of agricultural investments and their impact on agricultural output. The goal of this research is to identify that relation and quantitatively assess impact of investments on agricultural production value in Uzbekistan.

\section{Research results and discussion}

In order to diversify production, improve land and water allocation for irrigation, create a favourable agribusiness climate and a high added value chain, support the development of cooperative relations, widely introduce market mechanisms and information and communication technologies in the industry, as well as use science achievements and increase employees' potential (Decree of the President of the Republic of Uzbekistan "On Approving the Strategy for the Development of Agriculture of the Republic of Uzbekistan for 2020 - 2030 years" No. PD-5853, 23 October 2019.)

The President of the Republic of Uzbekistan Shavkat Mirziyoyev on 24 January 2020 announced the annual message to parliamentarians and the government of Uzbekistan. According to him: "...agriculture, which is one of the most important areas that ensure the growth of the economy, employment and incomes of the population, must be developed on the basis of a strategic approach". In connection with this, measures will be taken to significantly increase production, so that this year to reach the export parameters of fruits and vegetables of USD 2 billion and increase this figure by 3-4 times in the next 5-7 years. In addition, this year the state will spend 3 trillion UZS to the development of horticulture, viticulture, seed production, animal husbandry, agrology, the widespread introduction of water-saving technologies, research and training of qualified personnel for the field. 
In order to further improve and develop agriculture, the President of the Republic of Uzbekistan adopted a resolution on 17 April 2018 "on measures to radically improve the system of state management of agriculture and water management". In the resolution, a separate structure is allocated to the management of attracting investment. Earlier, in August 2017, a Centre for implementing investment projects in agriculture and water management was established. It was based on the relevant groups for the development and implementation of investment projects, taking into account the number of employees provided for by loan agreements and relevant Presidential decrees. The main tasks of the centre are:

- participation in attracting foreign investment, soft loans and technical assistance funds (grants), ensuring timely and effective implementation of investment projects in accordance with the principles of project management;

- ensuring the holding of tender (competitive) tenders in the prescribed manner on time, the conclusion of contracts, their examination in authorized bodies;

- monitoring the supply of equipment, materials and the performance of work and services under contracts in accordance with national legislation, international rules and procedures of relevant international financial institutions and foreign government financial organizations.

- Table 1 provides some information regarding agriculture.

Table 1

The impact of investment on agricultural development

\begin{tabular}{|c|c|c|c|c|}
\hline Years & $\begin{array}{c}\text { Investments in } \\
\text { Agriculture sector, } \\
\text { bln. UzS }\end{array}$ & $\begin{array}{l}\text { Agriculture gross } \\
\text { output, bln. UZS }\end{array}$ & $\begin{array}{l}\text { Agriculture, value } \\
\text { added, bln .UZS }\end{array}$ & $\begin{array}{l}\text { Food production } \\
\text { index, } \%\end{array}$ \\
\hline 2002 & 102,2 & 3255.3 & 2244.2 & 85.37 \\
\hline 2003 & 98.5 & 4083.3 & 2801.8 & 89.75 \\
\hline 2004 & 113.6 & 4615.8 & 3242.3 & 93.98 \\
\hline 2005 & 138.2 & 5978.3 & 4192.8 & 97.92 \\
\hline 2006 & 164.4 & 7538.8 & 5298.0 & 108.1 \\
\hline 2007 & 200.9 & 9304.9 & 6550.2 & 108.79 \\
\hline 2008 & 261.2 & 11310.7 & 7673.0 & 114.17 \\
\hline 2009 & 385.9 & 13628.6 & 9200.0 & 120.13 \\
\hline 2010 & 531 & 30856.7 & 21251.3 & 126.53 \\
\hline 2011 & 942.5 & 45285.9 & 30658.6 & 135.28 \\
\hline 2012 & 1089.2 & 55750 & 36954.6 & 141.03 \\
\hline 2013 & 1335.6 & 66435.3 & 42636.8 & 151.35 \\
\hline 2014 & 1448 & 81794.3 & 53613.2 & 147.42 \\
\hline 2015 & 1375.5 & 99604.6 & 64680.3 & 159.6 \\
\hline 2016 & 1646.4 & 115599.2 & 74779.0 & 157.08 \\
\hline 2017 & 2004.3 & 148199.3 & 90983.9 & N/A \\
\hline 2018 & 3561.1 & 192699.2 & 117315.8 & N/A \\
\hline
\end{tabular}

Source: author's calculations based on data from www.stat.uz and https://data.worldbank.org/indicator

Table 1 shows that the volume of investments in agriculture in 2002 amounted to 102.2 billion UZS, while in 2010 this volume increased 5 times and amounted to 531 billion UZS. In 2018, this amount increased by 6.7 times compared to 2010 and amounted to 3561.1 billion UZS.

Investments in the agricultural sector of Uzbekistan are one of the most important factors of its development. They need all the spheres of agro-industry: industries producing equipment (First agriculture sector), agriculture (Second agricultural sector) and processing industry (the third agricultural sector). Agriculture occupies a special place among the listed areas of the Republic's 
agro-industrial complex, since this area produces the initial product for processing industries and ultimately serves as the basis for its stable activity.

Therefore, we analysed the relationship between investment in agriculture and gross agricultural product. While investments in agriculture in 2018 increased by 34.8 times compared to 2002, the total value of gross agricultural output in 2018 amounted to 192699.2 billion sums and increased by 59 times compared to 2002 .

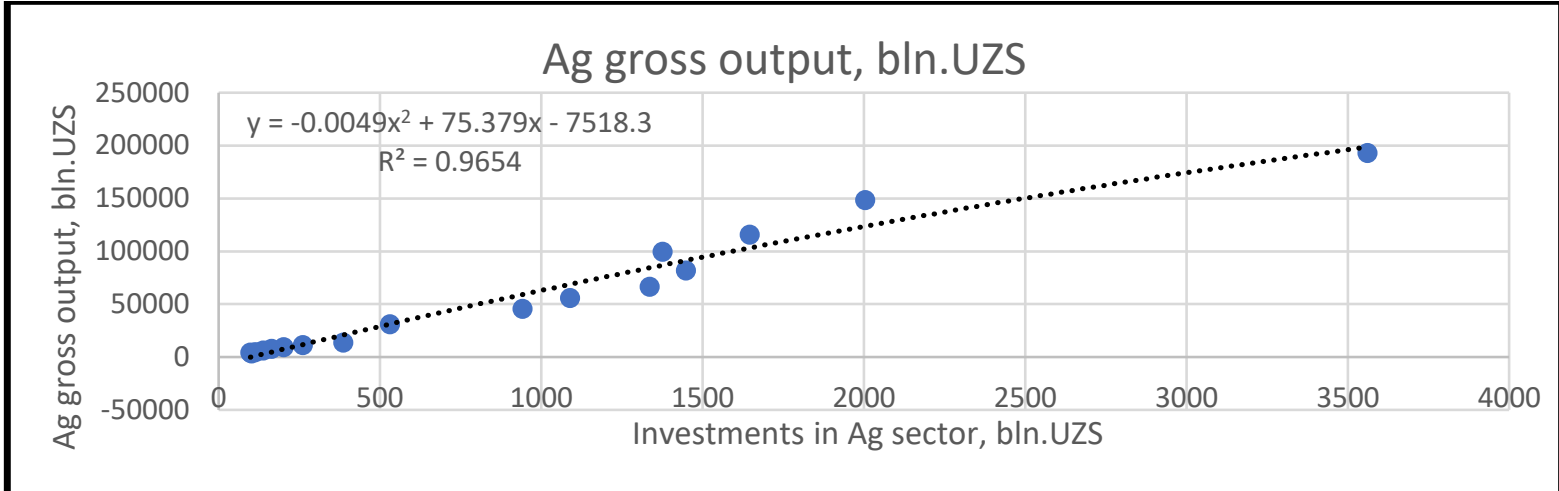

Source: author's calculations based on data from stat.uz

Fig. 1. The economic model of gross output of agriculture

As can be seen from the model in figure $1, \mathrm{R}^{2}=0.9654$, that is, there is a strong correlation between investment in agriculture and gross agricultural output.

It should be noted that one of the priority areas for the development of the agrarian sector, an important sphere of the economy of Uzbekistan, is filling the domestic market with food products, achieving self-sufficiency in the field of their production and ensuring food security. The effective implementation of these tasks allows us to solve such social problems as providing the population with jobs, improving the welfare of the population, and improving urban and rural areas. In Uzbekistan, the development and implementation of the state policy on food security is underway, providing for food safety and improving the diet, producing food products in the required quantity.

If we study the relationship between investments in agriculture and food production, we can see that there is a strong correlation between them, because $R^{2}=0.9713$ (figure 2 ).

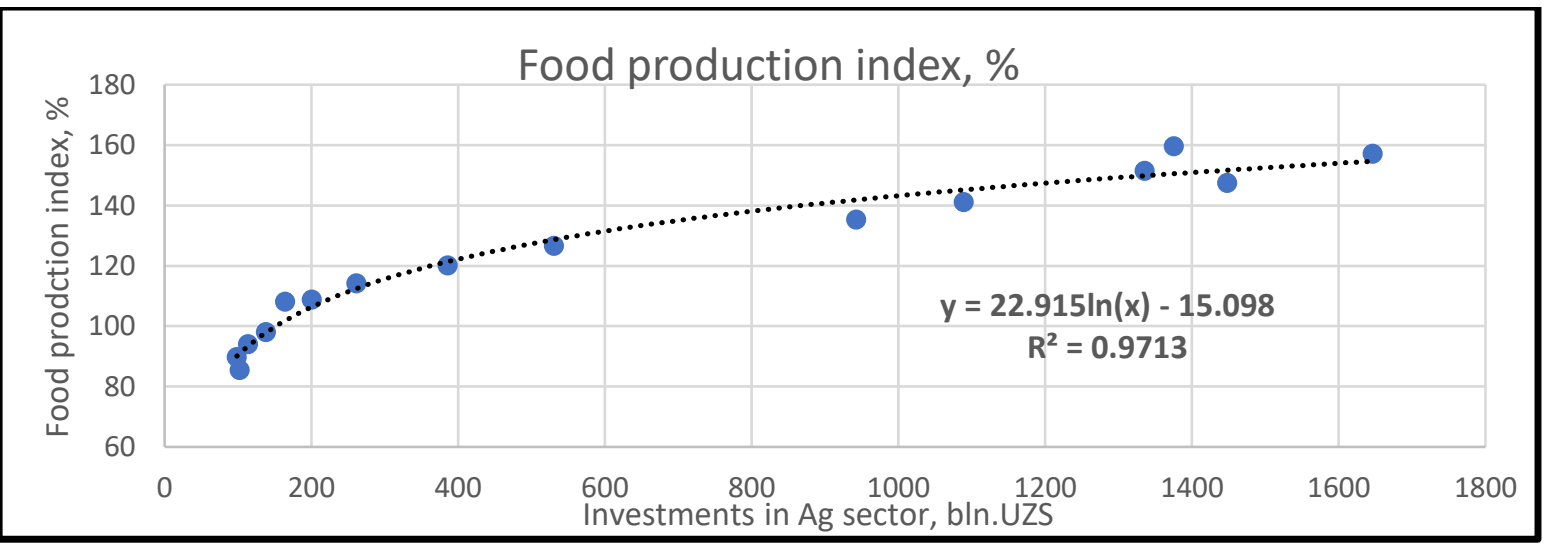

Source: author's calculations based on data from stat.uz

Fig. 2. Economic model of food production index

In Uzbekistan, it is of great importance to create a favourable agribusiness climate and value chain, which provide for the broad implementation of market principles in the purchase and sale of agricultural products, the development of quality control infrastructure, export promotion, and the production of high-value agri-food products that are competitive on target international markets. Below, we compared the relationship between investment in agriculture and value added in 
agriculture. The economic model shows a positive result, because $\mathrm{R}^{2}=0.9862$, the correlation between investment in agriculture and the value chain created in agriculture is very high and this means investment in agriculture is paying off (figure 3 ).

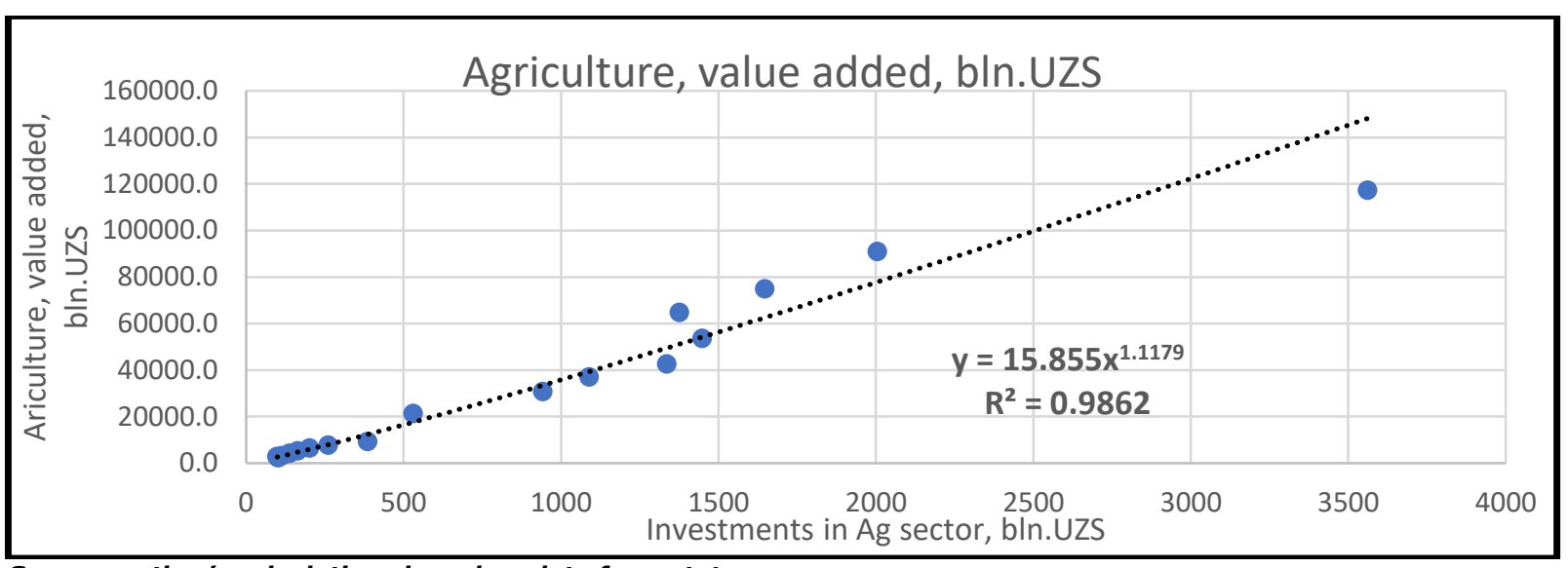

Source: author's calculations based on data from stat.uz

Fig. 3. Economic model of value added in agriculture

Thus, the results of the quantitative research indicate that there is a strong correlation between volume of the agricultural investments and its impact on production volume, food production index and value added index. Moreover, developed mathematical models demonstrate how investments will quantitatively impact grows of production volume, food production and value added indexes allow to forecast them depending on volume of investments. In other words, it demonstrates that investments into Agricultural sector of Uzbekistan are valuable because it leads to the increase of Agricultural production in general and food production particularly, and more value-added produce as well and thus ensures potential investors including foreign direct investors that agricultural sector is competitive to invest.

\section{Conclusions, proposals, recommendations}

Uzbekistan is encouraging investments into the sector. As market mechanisms, a cluster system has been introduced in the agricultural industry, the accelerated development of such special areas as the creation of modern greenhouse farms, fish farming, beekeeping, poultry farming, and so on, as well as the expansion of the practice of secondary autumn planting of vegetable crops, homestead farming contribute to deep structural reform. All this will attract domestic and foreign investors.

In the agricultural sector of the republic, investments at the state level are important. For the influx of investments at the state level, it is necessary to ensure the formation of a favourable economic market environment. This can be achieved by introducing a management mechanism that takes into account the specifics of the rural industry.

In modern conditions, one of the problems is attracting investors to the agricultural sector of the republic. Attraction of investors, first of all, depends on the investment attractiveness of the object. To determine the investment attractiveness of a particular area in comparison with others, it is necessary to take into account:

- economic potential of the district (natural and climatic conditions, infrastructure etc.);

- indicators of the efficiency of its use (including labour resources, fixed and working capital, fertilizers etc.);

- expected effect of capital investments.

Foreign investors are paying particular attention to legislation in the field of investment. It also takes into account the sectoral features of agriculture, such as the dependence of production on 
natural and climatic conditions, high capital intensity, the development of social and industrial infrastructure, the availability of state regulation measures (budget investments, state purchases of agricultural products, tax and credit benefits etc.).

Attracting investment is a difficult task, but it is even more difficult to ensure that it is used effectively. The effectiveness of investment in the agricultural sector is manifested primarily in the growth of labour productivity, increasing the output of gross output, reducing the capital intensity of production etc.

In the conditions in which the agro-industrial complex of the Republic, and especially the regions, is currently placed, the greatest interest is to find investments that contribute to the development of the agricultural sector.

In recent years, some work has been carried out in the direction of reforming the country's agriculture, in particular, improving the public administration system, widespread introduction of market relations, strengthening the legal foundations of relations between entities producing, processing and selling agricultural products, attracting investments to the industry, and introducing resource-saving technologies, as well as providing agricultural producers with modern equipment.

Modern approaches to solving urgent problems related to investing in the agricultural sector of the Republic can provide conditions for stable, efficient, rational, and expanded reproduction of the agricultural sector. Thus, in order to further develop the investment potential in the agricultural sector of the Republic, it is necessary to improve the existing forms and methods of investment. The proposed options for the development of the existing system of financing investments in agriculture are aimed at successfully solving current problems, and suggest that agricultural producers reach a qualitatively new level of investment activity that ensures cost-effective production.

\section{Bibliography}

1. Decree of the President of the Republic of Uzbekistan "On approval of the development strategy of agriculture of the Republic of Uzbekistan for 2020 - 2030" No. PD-5853, 23 October 2019. Retrieved: lex.uz

2. Kovalenko N.Ya. et al. Agricultural Economics. M.: Yurkniga, 2009. Agricultural Economics: Textbook. allowance / ed. V.T. Vodyannikov. M. Koloss, 2008. 388 p.

3. Message from the President of the Republic of Uzbekistan Shavkat Mirziyoyev Oliy Majlis 01/24/2020. Retrieved:http://uza.uz/ru/politics/poslanie-prezidenta-respubliki-uzbekistan-shavkata-mirziyeev-25-012020 Access: 17.02 .2020

4. Maksumkhonova A.M. Investments as a factor in the development of the agricultural sector of the Republic of Uzbekistan // Bulletin of Science and Education No. 2 (56). Part 2 2019.p. 40-43.

5. Main indicators of social and economic development of the Republic of Uzbekistan for 2000-2019. Retrieved: https://stat.uz/en/181-ofytsyalnaia-statystyka-en/2806-quarterly-reports Access: 21.01 .2020

6. Table "Main indicators of agriculture" 2000-2018. Retrieved: www.stat.uz Access: 17.12.2019

7. Resolution of The President R. Uz. 17.04.2018 no. III1-3671 "on measures for organizing the activities of the Ministry of agriculture of the Republic of Uzbekistan". Retrieved: lex.uz Access: 25.10.2018 